INTIQAD: JURNAL AGAMA DAN PENDIDIKAN ISLAM

ISSN 1979-9950 (print) || ISSN 2598-0033 (online), http://jurnal.umsu.ac.id/index.php/intiqad DOI: https://doi.org/10.30596/intiqad.v11i1.2445

Vol. 11, No. 1 (Juni 2019)

\title{
Eksistensi Jurusan Hukum Ekonomi Syariah IAIN Langsa
}

\author{
Zainal Abidin ${ }^{1 *}$, Agustinar $^{2}$, Maulina Ulfanur ${ }^{3}$, Rasfadli $^{4}$ \\ Institut Agama Islam Negeri (IAIN) Langsa ${ }^{1,2,3,4}$ \\ *1email: zainalabidin@gmail.com \\ 2email: agus.tinar2508@gmail.com \\ 3 email:maulinaulfanur@gmail.com \\ 4email:handsfadli@gmail.com
}

\begin{tabular}{|c|c|}
\hline Abstract & Artikel Info \\
\hline $\begin{array}{l}\text { This study aims to analyze the effect of curriculum, } \\
\text { lecturer quality, academic service quality and alumni } \\
\text { competence on the existence of Islamic Economics Law } \\
\text { Department IAIN Langsa. The population in this study } \\
\text { were all alumni of the Islamic Economics Law Department } \\
\text { (HES) of Langsa IAIN, while the sample used in this study } \\
\text { was that some alumni had worked, so the samples } \\
\text { taken were } 60 \text { HES IAIN Langsa alumni. The sampling } \\
\text { technique used was nonprobability sampling with a type of } \\
\text { purposive sampling. The research methodology uses a } \\
\text { survey method with a quantitative approach. Data } \\
\text { analysis using Multiple Linear Regression analysis using } \\
\text { SPSS Version 20 Software. The results of this study } \\
\text { indicate that the curriculum (X) has a positive effect on } \\
\text { the existence of the HES Department (Y) with t-values } \\
\text { (2,267)>t-table (1.67), then (H is accepted). The quality } \\
\text { of the Lecturer (X) has a positive effect on Existence } \\
\text { (Y) with a } t \text { - value (4.271)>t-table (1.67), then (H }{ }_{2} \text { is } \\
\text { accepted). Academic service quality (X) has a positive } \\
\text { effect on the existence of the HES Department (Y) } \\
\text { with a t-value (2.886)>t-table (1.67), then (H3 is } \\
\text { accepted). Alumni Competence (X) has a positive effect } \\
\text { on Existence (Y) with a t-value (3,920)> t-table (1.67), } \\
\text { then (H4 is accepted). Of the several variables that have } \\
\text { been tested by lecturer quality which have a dominant } \\
\text { influence on the existence of the Islamic Economics Law } \\
\text { Department with the resulting t-value of 4.271 which is the } \\
\text { highest } t \text {-value. } \\
\text { Keywords : Existence, Curriculum, Quality of Lecturers, } \\
\text { Service Quality and Alumni Competence }\end{array}$ & $\begin{array}{c}\text { Received: } \\
\text { 24 Januari } 2019 \\
\text { Revised: } \\
\text { 20 Maret } 2019 \\
\text { Accepted: } \\
\text { 23 April 2019 } \\
\text { Published: } \\
\text { 20 Juni 2019 }\end{array}$ \\
\hline \multicolumn{2}{|l|}{ Abstrak } \\
\hline Penelitian ini bertujuan untuk menganalisis pengaruh & \\
\hline
\end{tabular}


kurikulum, mutu dosen, kualitas pelayanan akademik dan kompetensi alumni terhadap eksistensi Jurusan Hukum Ekonomi Syariah IAIN Langsa. Populasi dalam penelitian ini adalah seluruh alumni pada Jurusan Hukum Ekonomi Syariah (HES) IAIN Langsa, sedangkan Sampel yang digunakan dalam penelitian ini adalah sebagian alumni telah bekerja, maka sampel yang diambil sebanyak 60 alumni HES IAIN Langsa. Teknik pengambilan sampel yang digunakan adalah nonprobability sampling dengan jenis purposive sampling. Metodologi penelitian menggunakan metode survey dengan pendekatan kuantitatif. Analisis data menggunakan analisis Regresi Linear Berganda dengan menggunakan Software SPSS Versi 20. Hasil penelitian ini menunjukkan bahwa Kurikulum $\left(\mathrm{X}_{1}\right)$ berpengaruh posit if terhadap Eksistensi Jurusan HES (Y) dengan nilai t-hitung $(2,267)>t$-tabel $(1,67)$, maka $\left(\mathrm{H}_{1}\right.$ diterima). Mutu Dosen $\left(\mathrm{X}_{2}\right)$ berpengaruh posit if terhadap Eksistensi (Y) dengan nilai t-hitung $(4,271)>$ t-tabel $(1,67)$, maka $\left(\mathrm{H}_{2}\right.$ diterima). Kualitas pelayanan akademik $\left(\mathrm{X}_{3}\right)$ berpengaruh posit if terhadap eksistensi Jurusan HES (Y) dengan nilai t-hitung $(2,886)>$ t-tabel $(1,67)$, maka $\left(\mathrm{H}_{3}\right.$ diterima). Kompetensi Alumni $\left(\mathrm{X}_{4}\right)$ berpengaruh posit if terhadap Eksistensi (Y) dengan nilai t-hitung $(3,920)>$ t-tabel $(1,67)$, maka $\left(\mathrm{H}_{4}\right.$ diterima). Dari beberapa variabel yang sudah diuji mutu dosen yang berpengaruh dominan terhadap eksistensi Jurusan Hukum Ekonomi Syariah dengan nilai t-hitung yang dihasilkan adalah sebesar 4,271 yang merupakan nilai t-hitung tertinggi.

\section{Kata Kunci : Eksistensi, Kurikulum, Mutu Dosen, Kualitas Pelayanan dan Kompetensi Alumni}

\section{A. Pendahuluan}

Pendidikan merupakan faktor pendukung yang memegang peranan yang sangat penting di segala sektor. Manusia membutuhkan pendidikan dalam kehidupannya. Pendidikan adalah usaha agar manusia dapat mengembangkan potensi dirinya melalui proses pembelajaran dan/atau cara lain yang dikenal oleh masyarakat. Sistem Pendidikan Nasional memberikan dasar hukum untuk membangun pendidikan nasio nal dengan menerapkan prinsip Demokrasi, desentralisasi, otonomi, keadilan dan menjunjung tinggi hak asasi manusia. Penerapan ketentuan 
Vol. 11, No. 1 (Juni 2019)

dalam undang-undang ini diharapkan dapat mendukung segala upaya untuk memecahkan masalah pendidikan, guna memberikan sumbangan yang signifikan terhadap masalah-masalah makro bangsa Indonesia. ${ }^{1}$

Kualitas mutu pendidikan menjadi isu yang utama dalam konteks pendidikan di perguruan tinggi, tidak terkecuali pada Institut Agama Islam Negeri (IAIN) Langsa. Perguruan tinggi dikatakan bermutu apabila mampu menetapkan dan mewujudkan visinya melalui pelaksanaan misi, serta mampu memenuhi kebutuhan/me muaskan stakeholders yaitu kebutuhan masyarakat, dunia kerja dan profesional. Sehingga, perguruan tinggi harus mampu merencanakan, menjalankan dan mengendalikan suatu proses yang menjamin pencapaian mutu. Sebuah proses pendidikan yang bermutu tentunya harus juga didukung oleh faktor-faktor penunjang proses pendidikan yang bermutu pula.

Saat ini Fakultas Syar i'ah Institut Agama Islam Negeri

1 Wan Suryani dan Paham Ginting, "Faktor-faktor Yang Mempengaruhi Keputusan Mahasiswa Memilih Fakultas Ekonomi Universitas Islam Sumatera Utara Al Munawaroh Medan", Modernisasi, Volume 9, Nomor 1, Februari 2013, h. 33-34
(IAIN) Langsa telah berupaya untuk merespon kebutuhan angka kerja dibidang Hukum Ekonomi Syariah, disebabkan tingginya dinamika berbagai aspek kehidupan masyarakat. Persepsi masyarakat terhadap alu mni Fakultas Syari'ah masih kurang hal ini berdampak pada sikap dan cara memperlakukan Sar jana hukum ekonomi syariah.

Banyak masyarakat beranggapan bahwa jurusan Hukum Ekonomi Syariah hanya berorientasi pekerjaannya adalah di lembaga keuangan syariah saja, padahal jurusan Hukum Ekonomi Syariah mempunyai peluang kerja yang sangat luas. Selain mereka bisa bekerja dilembaga keuangan, mereka juga bisa berkecimpung di bidang Hukum. Karena pada dasarnya lulusan dari jurusan Hukum Ekonomi Syariah mempunyai dasar keilmuan hukum selayaknya gelar yang digunakan yaitu Sarjana Hukum. Bukan hanya masyarakat saja bahkan mahasiswa sendiripun masih beranggapan bahwa ketika mereka lulus nantinya akan bekerja dibidang lembaga keuangan khususnya di dunia perbankan. 
Vol. 11, No. 1 (Juni 2019)

Sebagai program studi yang sudah lama berdiri, sangat diperlukan perbaikan, evaluasi dan peningkatan pela yanan baik secara fisik maupun pelayanan non fisik. Fasilitas, sarana prasarana dan kelengkapan-kelengkapan akademik lainnya juga masih membutuhkan perbaikan. Salah satu umpan balik yang dibutuhkan oleh pengelola program adalah tingkat kepuasan mahasiswa dan masyarakat terhadap penyelenggaraan program tersebut.

Dengan mengetahui tingkat kepuasan mahasiswanya, pengelola program dapat membuat kebijakankebijakan, tindakan-tindakan dan sarana serta fasilitas pendukung yang dapat meningkatkan penyelenggaraan jurusan Hukum Ekonomi Syariah (HES) tersebut dimasa mendatang. Sebagai jurusan yang sekarang telah menghasilkan banyak lulusan, maka perlu diadakan penelitian untuk melakukan evaluasi terhadap tingkat kepuasan alumninya, hal ini dimaksudkan agar institut mengetahui sejauhmana kualitas pelayanan yang telah diberikan kepada para mahasiswa dan untuk melakukan peningkatan kualitas pelayanan dan pembelajaran.
Oleh karena itu peningkatan kinerja dosen di perguruan tinggi perlu dikembangkan yang berorientasi kepada mutu, sehingga mampu meningkatkan kontribusinya bagi kinerja perguruan tinggi yang pada gilirannya akan memberikan dampak pada mutu lulusan perguruan $t$ inggi yang berarti bagi keberhasilan pembangunan nasional. Aspek pelayanan menjadi salah satu faktor yang dapat meningkatkan program studi karena pelayanan merupakan hal yang berkaitan langsung dengan mahasiswa, selain itu perubahan paradigm manajemen perguruan tinggi yaitu bersifat melayani, harus diimbangi dengan perubaha budaya kerja dosen dan karyawan (employed) yang juga berorientasi pada pelayanan. Jika dahulu hubungan antara dosen dan mahasiswa bersifat patron and client, maka kini budayanya harus diubah menjadi hubungan kemitraan. Pada organisasi jasa termasuk pendidikan tinggi, produk jasa diterima oleh pelanggan pada saat terjadi interaksi antara dosen dengan penerima jasa (mahasiswa), sehingga kompetensi dosen dan kualitas proses pembelajaran dalam bekerja sangat 
INTIQAD: JURNAL AGAMA DAN PENDIDIKAN ISLAM

ISSN 1979-9950 (print) || ISSN 2598-0033 (online), http://jurnal.umsu.ac.id/index.php/intiqad DOI: https://doi.org/10.30596/intiqad.v11i1.2445

Vol. 11, No. 1 (Juni 2019)

menentukan kualitas produk jasa yang dihasilkan. $^{2}$

Alumni merupakan tolak ukur kesuksesan sebuah lembaga pendidikan. Hal ini mengindikasikan bahwa keberadaan alumni seharusnya dapat dijadikan kriteria keberhasilan sebuah lembaga pendidikan dalam mencetak produk lulusan yang berkualitas dan berdaya saing tinggi. Jika alumni dapat diserap secara maksimal di dunia kerja dan masyarakat sesuai dengan kompetensi yang dimilikinya, berarti perguruan tinggi tersebut telah sukses menjadi sebuah lembaga pendidikan yang berkualitas dan bermutu.

\section{B. Kajian Teoritis}

\section{Teori Eksistensi}

Eksistensi bisa juga dikenal denga satu kata yaitu keberadaan. Abidin Zaenal, menyatakan bahwa Eksistensi adalah suatu proses yang dinamis. ${ }^{3}$ Jadi eksistensi tidak bersifat kaku dan terhenti, melainkan lentur atau kenyal dan mengalami

2 Frizimmons, J. A and Mona, J. Frizimmons, Service Management: opration, Strategy and InformationTechnology, (NewYork: Mc Graw-Hill, 2001), p.3

3 Zainal Abidin, Filsafat Manusia, (Bandung: Remaja Rosdakarya, 2007), h. 16. perkembangan atau sebaliknya

kemunduran, tergantung pada

kemampuan dalam

mengaktualisasikan potensi-

potensinya.

\section{Kurikulum}

Kurikulum berasal dari bahasa Latin currere, yang berarti lapangan perlo mbaan lari. Kurikulum juga bisa berasal dari kata curriculum yang berarti a running course, dan dalam bahasa Prancis dikenal dengan carter berarti to run (berlari). ${ }^{4}$ Menurut $\mathrm{J}$. Galen Sailor dan William M Alexander, curriculum is defined reflects volume judgments regarding the nature of education. The definition used also influences haw curriculum will beplanned and untilized. Kurikulum merupakan nilai-nilai keadilan dalam inti pendidikan. Istilah tersebut mempengaruhi terhadap kurikulum yang akan direncanakan dan dimanfaatkan.

Secara termino logi, kurikulum berarti suatu program pendidikan yang berisikan berbagai bahan ajar dan pengalaman belajar yang diprogramkan, direncanakan dan

\footnotetext{
4 BSNP, Pedoman Penyusunan Kurikulum Tingkat Satuan Pendidikan Jenjang Sekolah Dasar, Jakarta: BSNP, 2008), h.1
} 
Vol. 11, No. 1 (Juni 2019)

dirancangkan secara sistematika atas dasar norma-norma yang berlaku dan dijadikan pedoman dalam proses pembelajaran bagi pendidik untuk mencapai tujuan pendidikan. ${ }^{5}$

Menurut Dakir kurikulum itu memuat semua program yang dijalankan untuk menunjang proses pembelajaran. Program yang dituangkan tidak terpancang dari segi administrasi saja tetapi menyangkut keseluruhan yang digunakan untuk proses pembelajaran.

Menurut Nasution kurikulum adalah suatu rencana yang disusun untuk melancarkan proses belajar mengajar di bawah bimbingan dan tanggung jawab sekolah atau lembaga pendidikan beserta staf pengajarnya. $^{6}$

Menurut Undang-Undang No. 20 Tahun 2003 tentang system pendidikan nasio nal dan Peraturan Pemerintah Republik Indonesia No. 19 tahun 2005 tentang Standar Nasional Pendidikan di sana dijelaskan, bahwa kurikulum adalah seperangkat

${ }^{5}$ Dakir, Perencanaan dan Pengembangan Kurikulum, (Yogyakarta: Rineka Cipta, 2004), h. 3.

6 Nasution, S., Kurikulum dan Pengajaran, (Jakarta: Bina Aksara, 1989), h. 5 rencana dan pengaturan mengenai tujuan, isi dan bahan pelajaran serta cara yang digunakan sebagai pedoman penyelenggaraan kegiatan pembelajaran untuk mencapai tujuan pendidikan tertentu. ${ }^{7}$

Menurut Nurgiantor, bahwa komponen-komponen kurikulum, yaitu: ${ }^{8}$ a. Komponen tujuan, mempunyai tiga jenis tahapan, yaitu: 1) Tujuan jangka panjang; 2) Tujuan jangka menengah; 3) Tujuan jangka dekat.

Dalam sebuah kurikulum lembaga pendidikan terdapat dua tujuan, yaitu: 1) Tujuan yang dicapai secara keseluruhan; 2) Tujuan yang ingin dicapai oleh setiap bidang studi.

b. Komponen isi/materi. Isi program kurikulum adalah segala sesuatu yang diberikan kepada anak didik dalam kegiatan belajar mengajar dalam rangka mencapai tujuan. Isi kurikulum meliputi jenis-jenis bidang studi yang diajarkan dan isi masing-masing bidang studi tersebut. Bidang studi itu disesuaikan

${ }^{7}$ BSNP, Pedoman Penyusunan Kurikulum Tingkat Satuan Pendidikan...h.6.

8 Nurgiyantoro, Burhan, Dasar-Dasar Pengembangan Kurikulum Sekolah; Sebuah Pengantar Teoritis dan Pelaksanaan, (Yogyakarta: BPFE, 2004), h. 16 
Vol. 11, No. 1 (Juni 2019)

dengan jenis, jenjang, maupun jalur pendidikan yang ada. Kriteria yang dapat dijadikan pertimbangan, antara lain: 1) Kebermaknaan; 2) Manfaat atau kegunaan; 3) Pengembangan manusia.

c. Komponen Media (sarana dan prasarana)

Media merupakan sarana prasarana dalam pembelajaran. Media merupakan perantara untuk menjabarkan isi kurikulum agar lebih mudah dipahami oleh peserta didik dan agar memiliki retensi optimal.

Pengembangan Kurikulum Ekonomi syariah dari beberapa faktor yang mempengaruhi kualitas lulusan suatu lembaga pendidikan, kurikulum dianggap menjadi prioritas utama untuk diperhatikan. Hal ini tidak lain karena kurikulum merupakan rencana pendidikan yang akan diberikan kepada mahasiswa. Bahkan dalam pengertian lebih luas, keberadaan kurikulum tidak saja terbatas pada materi yang akan diberikan di dalam ruang kuliah, melainkan juga meliputi apa saja yang sengaja diadakan atau dit iadakan untuk dialami mahasiswa di dalam kampus. ${ }^{9}$

\footnotetext{
${ }^{9}$ BSNP, Pedoman Penyusunan Kurikulum Tingkat Satuan Pendidikan...h.10.
}

Secara prinsip ada dua model penyusunan kurikulum, yaitu model subject matter dan model kompetensi/topik inti. Model subject matter menggunakan pola deduktif dalam penyusunan kurikulumnya yaitu dengan cara menentukan struktur kurikulum atau mata kuliah sebagai patokan. Akan tetapi, model KBK menggunakan pola induktif dalam penyusunannya yaitu, penyusunan kurikulum dan penentuan mata kuliah didasarkan pada pengalaman belajar yang harus diberikan pada pemahaman mahasiswa yang dirumuskan dalam pencapaian kompetensi yang telah dirancang.

Bagi pengelolaan pendidikan yang sedang berjalan dengan pengalaman yang memadai dalam mengaplikasikan kurikulum dengan model subject matter dan dalam perkembangannya mengorientasikan pelaksanaan kurikulumnya/ pembelajarannya pada basis kompetensi, maka pola pengembangan kurikulumnya biasa menggunakan pola deduktif-induktif, sehingga pengembangan kurikulum tersebut didasarkan pada penyusunan standar isi yang didalamnya menyangkut standar 


\section{Vol. 11, No. 1 (Juni 2019)}

kompetensi (SK), kompetensi dasar (KD), dan struktur kurikulum. ${ }^{10}$

\section{Pengembangan Pendidikan Tinggi}

Hukum Ekonomi Syariah Untuk melahirkan SDM yang berkompeten di bidang bisnis dan hukum syari'ah secara komprehensif dan memadai, serta memiliki integritas tinggi, maka dibutuhkan lembaga pendidikan hukum ekonomi syari'ah yang secara khusus menyiapkan SDM hukum ekonomi syari'ah. Karena itu perlu adanya redesign tentang institusi kependidikan di Indonesia terutama di fakultas Hukum, agar dapat dihasilkan sarjana yang mempunyai keahlian tentang hukum ekonomi syari'ah dan memiliki budi pekerti yang sesuai dengan syariah Islam dan dapat diaplikasikan di sektor ekonomi.

\section{Kompetensi Alumni}

Seorang alumnus atau alumna adalah mantan siswa dan biasanya lulusan dari suatu institusi pendidikan (sekolah, perguruan tinggi, universitas). Menurut Departemen Pendidikan

\footnotetext{
${ }^{10}$ Dantes Nyoman, Upaya Peningkatan Pengelolaan Proses Pembelajaran Melalui Pendampingan pada Implementasi Kurikulum 2013, E-Journal Program Pascasarjana Universitas Pendidikan Ganesha, Vol.4, No.1, 2014), h. 12.
}

Amerika Serikat, kata alumnae dipakai untuk perguruan tinggi wanita atau sekelompok siswi. Kata alumni dipakai untuk perguruan tinggi pria, sekelompok siswa, atau campuran siswa-siswi.

"Alumni" (bentuk jamak) sering salah digunakan sebagai bentuk tunggal untuk kedua jenis kelamin; misalnya, "Saya alumni universitas ini," bukannya "Saya alumnus/alumna universitas ini". Pemakaian ini salah baik dalam konteks formal atau historis. Kemungkinan terjadinya salah pemakaian ini adalah karena ketidaktahuan tentang tata bahasa Latin dan kenyataan bahwa banyak dokumen cetak dan barang universitas yang menggunakan bentuk jamak dari kata ini.

\section{Teori Stakeholder}

Definisi stakeholder menurut Freeman dan McVea (2001) adalah setiap kelompok atau individu yang dapat mempengaruhi atau dipengaruhi oleh pencapaian tujuan organisasi. ${ }^{11}$ Teori stakeholder adalah teori yang menggambarkan kepada pihak mana saja perusahaan bertanggungjawab. Perusahaan harus menjaga hubungan

${ }^{11}$ Freeman R. E., Strategic Management: A stakeholder Approach, (Bostom: Pitman, 2001), h. 45 
INTIQAD: JURNAL AGAMA DAN PENDIDIKAN ISLAM

ISSN 1979-9950 (print) || ISSN 2598-0033 (online), http://jurnal.umsu.ac.id/index.php/intiqad DOI: https://doi.org/10.30596/intiqad.v11i1.2445

Vol. 11, No. 1 (Juni 2019)

dengan stakeholder-nya dengan mengakomodasi keinginan dan kebutuhan stakeholder-nya, terutama stakeholder yang mempunyai power terhadap ketersediaan sumber daya yang digunakan untuk aktivitas operasional perusahaan, misal tenaga kerja, pasar atas produk perusahaan dan lain-lain. ${ }^{12}$

\section{Hipotesis Penelitian}

Hipotesis penelitian adalah suatu penjelasan sementara tentang prilaku, fenomena atau keadaan tertentu yang telah terjadi atau akan terjadi. Berdasarkan rumusan masalah, tujuan, teori, penelitian terdahulu, dan kerangka pemikiran, maka hipotesis dalam penelitian ini adalah Hipotesis dalam penelitian ini secara simultan, yaitu:

1. $\mathrm{H}_{02}=$ Kurikulum tidak berpengaruh signifikan terhadap Eksistensi Jurusan HES

$\mathrm{H}_{\mathrm{a} 2}=$ Kurikulum berpengaruh signifikan terhadap Eksistensi Jurusan HES

2. $\mathrm{H}_{03}=$ Mutu Dosen tidak

${ }^{12} \mathrm{~A}$. Chariri dan Imam Ghazali, Teori Akuntansi, (Semarang: Balai Penerbit Universitas Diponogoro, 2007), h. 38 berpengaruh signifikan terhadap

Eksistensi Jurusan HES

$\mathrm{H}_{\mathrm{a} 3}=$ Mutu Dosen berpengaruh signifikan terhadap Eksistensi Jurusan HES

3. $\mathrm{H} 04=$ Kualitas Pelayanan Akademik tidak berpengaruh signifikan terhadap Eksistensi Jurusan HES

$\mathrm{H}_{\mathrm{a}} 4=\quad$ Kualitas Pelayanan Akademik berpengaruh signifikan terhadap Eksistensi Jurusan HES

4. $\mathrm{H}_{05}=$ Kompetensi Alumni tidak berpengaruh signifikan terhadap Eksistensi Jurusan HES

$\mathrm{H}_{\mathrm{a} 5}=$ Kompetensi Alumni berpengaruh signifikan terhadap Eksistensi Jurusan HES

\section{Metodologi Penelitian}

Jenis penelitian yang akan dilakukan dalam penelitian ini menggunakan metode survey. Penelitian survey merupakan penelitian yang mengumpulkan informasi dari suatu sampel dengan menanyakan melalui angket atau interview supaya nantinya menggambarkan berbagai aspek dari populasi. Metodologi yang 


\section{Vol. 11, No. 1 (Juni 2019)}

akan digunakan dalam penelitian ini adalah dengan metode kuantitatif yaitu pendekatan yang menekankan pada pengujian teori-teori atau hipotesishipotesis melalui pengukuran variabelvariabel penelitian dalam angka (quantitative) dan melakukan analisis data dengan prosedur statis dan pemodelan sistematis. $^{13}$ Dalam penelitian ini metode kuantitatif yang akan dilakukan adalah dengan mengkaji pengaruh antara Variabel yang digunakan dalam penelitian terdiri dari Eksistensi Jurusan HES, Kurikulum, Mutu Dosen, Kualitas Pelayanan Akademik dan Kompetensi Alumni.

Lokasi penelitian ini mencakup di 3 (tempat) kabupaten/kota di Aceh yaitu Kab. Aceh Timur, Kota Langsa, dan Kab. Aceh Tamiang. Alasan mengambil lokasi atau tempat ini dengan pertimbangan keberadaan 3 (tiga) kota ini merupakan tempat dimana para alumni Jurusan HES pernah bekerja sekurangnya pernah melaksanakan Praktik Kerja Lapangan ketika mereka menyandang status sebagai mahasiswa. Dan waktu

${ }^{13}$ Sujuko, Efferin dkk, Metode Penelitian Akuntansi, (Yogyakarta: Graha Ilmu, 2008), h. 47 penelitian akan dilakukan pada bulan April 2018 dan berakhir pada bulan September 2018.

Batasan operasional penelitian ini adalah menganalisis faktor-faktor yang mempengaruhi eksistensi Jurusan HES IAIN Langsa Di Aceh Timur Raya dimana Eksistensi Jurusan HES IAIN Langsa sebagai variabel dependen (Y), Kurikulum sebagai variabel independen $\left(\mathrm{X}_{1}\right)$, Mutu Dosen $\left(\mathrm{X}_{2}\right)$, Kualitas Pelayanan Akademik $\left(\mathrm{X}_{3}\right)$ serta Kompetensi Alumni ( $\left.\mathrm{X}_{4}\right)$. Adapun definisi operasional merupakan penjabaran akan definisi variabel dan indikator pada penelitian ini, yaitu meliputi Eksistensi, Kurikulum, Mutu Dosen, Kualitas Pelayanan Akademik, dan Kompetensi Alumni.

Populasi adalah wilayah generalisasi yang terdiri atas objek atau subjek yang mempunyai kualitas dan karakteristik tertentu yang ditetapkan oleh peneliti untuk dipelajari dan kemudian ditarik kesimpulannya. ${ }^{14}$ Populasi dalam penelitian ini adalah seluruh alumni pada Fakultas Syariah Jurusan Hukum

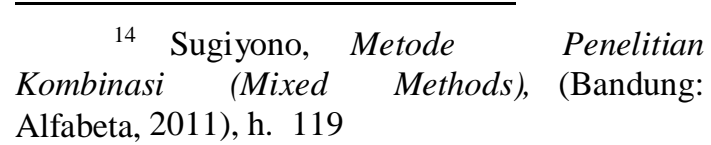


Vol. 11, No. 1 (Juni 2019)

Ekonomi Syariah (HES) IAIN Langsa di 3 (tiga) kabupaten/kota di Aceh Timur

Raya. Sampel yang digunakan dalam penelitian ini adalah sebagian alumni yang belum bekerja dan mahasiswa yang telah bekerja. Teknik pengambilan sampel yang digunakan adalah nonprobability sampling dengan jenis purposive sampling, yaitu teknik pengambilan sampel dengan pertimbangan bahwa responden adalah mahasiswa yang telah lulus mata kuliah kewirausahaan.

\section{E. Hasil Penelitian dan Pembahasan \\ 1. Gambaran Umum IAIN Langsa}

\section{a. Sejarah IAIN Langsa}

Cikal bakal Institut Agama Islam Langsa bernama Zawiyah Cot Kala Langsa) didirikan pada tahun 1980 adalah berdasarkan hasil keputusan Seminar Sejarah Islam di Rantau, Aceh Tamiang (dahulu dalam wilayah Aceh Timur). Nama "Zawiyah Cot Kala" tersebut diambil dari nama lembaga pendidikan tinggi yang terbesar dan tertua di Asia Tenggara yaitu "Dayah Cot Kala" yang pada mula didirikan dipimpin oleh Teungku Chiek Muhammad Amin yang merupakan salah satu Kerajaan Peureulak yang terletak di Bayeun, Aceh Timur abad ke-4 Hijriah. ${ }^{15}$ Sebagai bentuk realisasi dari hasil seminar tersebut, melalui inisiatif oleh M. Hasan ZZ, B.A. (Kakandepag Aceh Timur saat itu), Drs. T.M. Arifin Amin, Drs. Azhar Zakaria (Ka. MAN pada saat itu), H. Zainuddin Saman dan Drs. Idris Harahap serta dukungan dari pemerintah dan berbagai lapisan masyarakat, maka berdirilah Institut Agama Islam Zawiyah Cot Kala Langsa.

Pada tahap awal pendirian, Institut Agama Islam Zawiyah Cot Kala Langsa memiliki tiga fakultas yaitu Fakultas Syariah, Fakultas Tarbiyah, dan Fakultas Dakwah. Pembukaan kuliah pertama sekali dilakukan pada tanggal 14 Oktober 1980, namun hanya 2 (dua) fakultas yang diresmikan, yaitu Fakultas Tarbiyah Jurusan Pendidikan Agama Islam dan Fakultas Dakwah Jurusan Penerangan dan Penyiaran Agama Islam (PPAI) dengan jenjang Sarjana Muda. Sebagai payung lembaga ini, maka Pada tahun 1981 dibentuklah sebuah yayasan

\footnotetext{
${ }^{15}$ Wawancara dengan Humas IAIN
} Langsa. 
Vol. 11, No. 1 (Juni 2019)

dengan Akta Notaris No.7 tanggal 21 Juli 1981. Selanjutnya pada tahun 1982, bersamaan dengan kunjungan Menteri Agama Republik Indonesia H. Alamsjah Ratoe Perwiranegara ke Langsa dalam rangka peresmian Kantor Departemen Agama Kabupaten Aceh Timur Provinsi Daerah Istimewa Aceh yang berlokasi di Langsa, Aceh, pengurus Yayasan menyampaikan Surat Pemohonan Terdaftar untuk lembaga ini. Setahun kemudian, terbitlah SK Status Terdaftar oleh Dirjen Pembinaan Kelembagaan Agama Islam Departemen Agama RI Nomor: $\quad$ Kep/E/III/PP.00.2/1303/83 pada tanggal 16 April 1983. Kemudian pada tahun 1988 melalui Keputusan Menteri Agama Republik Indonesia Nomor 219 tahun 1988 tanggal 1 Desember 1988, Insitut Agama Islam Zawiyah Cot Kala Langsa mendapatkan status Terdaftar sampai dengan jenjang S-1. Namun, di tahun 1997 lembaga ini beralih status menjadi Sekolah Tinggi Agama Islam.

Dalam proses dari tahun ke tahun, lembaga pendidikan ini menunjukkan perkembangan dan peningkatan, baik dari sisi akademik, tenaga pengajar, maupun infrastruktur pendukung lainnya. Atas prestasinya itu, pada tahun 2000 lembaga ini mendapatkan peningkatan status menjadi Diakui berdasarkan Keputusan Direktur Jenderal Pembinaan Kelembagaan Agama Islam Departemen Agama Republik Indonesia Nomor: E/36/2000 tanggal 20 Maret 2000 dengan dua jurusan yaitu Jurusan Pendidikan Agama Islam (PAI) serta Jurusan Komunikasi dan Penyiaran Islam (KPI). Sebagai upaya pengembangan kelembagaan, pada tahun 2001 Sekolah Tinggi Agama Islam Zawiyah Cot Kala Langsa membuka Program Diploma Dua (D-II) untuk 2 (dua) jurusan baru yaitu Jurusan Guru Pendidikan Agama Islam (GPAI) dan Jurusan Pendidikan Guru Madrasah Ibtidaiyah (PGMI).

Upaya pengembangan dan peningkatan kualitas terus dilakukan. Perkembangan yang amat menggembirakan yaitu pada akhir tahun 2006, Sekolah Tinggi Agama Islam Zawiyah Cot Kala Langsa berubah status menjadi Sekolah Tinggi Agama Islam Negeri (STAIN) dengan diterbitkannya Peraturan Presiden RI Nomor 106 Tahun 2006 Tanggal 28 Desember 2006 Tentang Pendirian Sekolah Tinggi Agama Islam Negeri (STAIN) Zawiyah Cot Kala Langsa 


\section{Vol. 11, No. 1 (Juni 2019)}

yang ditandatangani oleh Presiden Republik Indonesia ke-6 Bapak Dr. H. Susilo Bambang Yodhoyono.

Dengan status penegeriannya selama delapan tahun di bawah kepemimpinan Bapak Dr. H. Zulkarnaini, M.A., lembaga ini mengalami peningkatan yang cukup signifikan, baik dari sisi manajemen, akademik, sarana prasarana, kelembagaan, ketenagaan, jumlah mahasiswa, maupun aspek-aspek lainnya. Kemajuan-kemajuan tersebut mengantarkan Sekolah Tinggi Agama Islam Negeri Zawiyah Cot Kala Langsa menjadi Institut Agama Islam Negeri Langsa dengan ditandatanganinya Peraturan Presiden Republik Indonesia Nomor 146 Tahun 2014 pada tanggal 17 Oktober 2014 oleh Presiden Republik Indonesia ke-6 Bapak Dr. H. Susilo Bambang Yudhoyono.

Kehadiran Institut Agama Islam Negeri Langsa memiliki arti penting untuk menerjemahkan makna Tri Dharma Perguruan Tinggi ke dalam program dan kegiatan yang terarah sesuai dengan kebutuhan masyarakat dan perkembangan zaman. Untuk itu, Institut Agama Islam Negeri Langsa menetapkan kebijakan serta rencana pengembangan agar lembaga ini dapat mempersiapkan generasi intelektual yang mempunyai moralitas dan tanggung jawab yang tinggi guna menghadapi arus era globalisasi. Pengembangan ini pula diharapkan mampu untuk memberikan prioritas utama terhadap pengembangan ilmu serta pembinaan mental dan spiritual.

Perubahan status dari STAIN ke IAIN merupakan bentuk responsif kebutuhan pendidikan masyarakat di bidang pendidikan agama. Juga mempercepat peningakatan sumber daya manusia yang bernuansa Islami, serta memperluas akses pendidikan tinggi Islam yang memiliki standar. Selain itu, dengan status IAIN tersebut, juga akan lebih meningkatkan pembangunan keagamaan bagi masyarakat Aceh, khususnya Kota Langsa. Serta meningkatkan kualitas penerapan syariat Islam di berbagai aspek kehidupan sesuai dengan kualitas intelektual SDM yang ada.

Institut Agama Islam Negeri Langsa dalam perjalannnya telah memiliki nilai-nilai budaya tersendiri dalam hati masyarakat Aceh Timur dan sekitarnya, karena keberadannya telah mewarnai corak pemikiran dan adat 
Vol. 11, No. 1 (Juni 2019)

istiadat masyarakat Aceh Timur, Kota Langsa dan Aceh Tamiang, di samping itu posisi yang strategis terletak di wilayah tiga pemerintah kabupaten/kota yang merupakan sebagai pusat perkembangan ilmu pengetahuan. Posisi strategis ini terbentuk melalui lembaga kajian keagamaan yang berkembang di pesantren (dayah) dan madrasah akan mengarah kepada pengkajian dan pengembangan ilmu ke-Islaman secara objektif dan rasional.

Oleh karena itu peningkatan status Sekolah Tinggi menjadi Institut akan menempatkan posisi dan fungsinya sebagai pusat kajian Islam di tingkat lokal, yang secara berantai akan mempengaruhi di tingkat regional dan nasional. Di samping itu pengembangan Institut ini akan memacu tumbuh kembali kekuatan persatuan umat Islam di nusantara, karena dasar utama dari semangat persatuan itu terbit di Peureulak dan akan bersinergi dengan semangat persatuan nasional.

\section{b. Program Studi/Jurusan Hukum Ekonomi Syariah (HES)}

Hukum Ekonomi Syariah pada dasarnya adalah belajar ekonomi dengan dilandaskan dan disesuaikan dengan prinsip-prinsip syariah. Ekonomi secara bahasa artinya tata kelola rumah tangga. Ekonomi itu sendiri maksudnya aktivitas manusia dalam memenuhi kebutuhannya. Jadi dalam ilmu ekonomi, kita mempelajari teori-teori ekonomi secara mikro maupun makro. Gunanya, kita jadi bisa berpikir logis dalam mengambil keputusan yang terbaik dalam memenuhi kebutuhan sebagai individu, perusahaan, maupun pemerintah nantinya. Syariah secara bahasa artinya jalan, aturan, dll. Secara istilah, syariat Islam adalah semua aturan yang Allah turunkan untuk para hamba-Nya (melalui nabi Muhammad), baik terkait masalah aqidah, ibadah, muamalah, adab, maupun akhlak. Baik terkait hubungan makhluk dengan Allah, maupun hubungan antar-sesama makhluk.

1) Visi Jurusan Hukum Ekonomi Syariah (Muamalah): menjadi Kiblat Kajian Hukum Ekonomi Syariah di Asia Tenggara dengan karakter Pendidikan Rahmatan Lil 'Alamin Pada Tahun 2035.

2) Misi Jurusan Hukum Ekonomi Syariah (Muamalah) 


\section{Vol. 11, No. 1 (Juni 2019)}

Adapun Misi Jurusan Hukum

Ekonomi Syariah (Muamalah, adalah sebagai berikut:

a) Mengembangkan Pendidikan Hukum Ekonomi Syariah Berbasis Fikih dan

b) Perundang-Undangan secara integratif

c) Melaksanakan penelitian, penerbitan jurnal dan penulisan buku berstandar

d) Internasional

e) Melakukan pengabdian kepada masyarakat dalam bidang hukum ekonomi syariah

f) Menciptakan program unggulan bagi peningkatan skill sebagai analis dan praktisi perbankan dan lembaga keuangan syariah lainnya

g) Melakukan kerjasama dengan pihak ketiga untuk pengembangan program studi

h) Meningkatkan SDM dosen dan tenaga kependidikan

i) Mengembangkan kegiatan ADM berbasis IT

\section{Hasil Penelitian}

\section{a. Karakteristik Responden}

Responden penelitian adalah alumni Jurusan Hukum Ekonomi Syariah Fakultas Syariah IAIN Zawiyah Cot Kala Langsa yang telah bekerja dengan jumlah responden sebanyak 60 alumni dengan karakteristik responden dilihat dari segi Jurusan, jenis kelamin, umur, dan latar belakang keluarga apakah berasal dari keluarga wirausaha atau nonwirausaha, berdasarkan data yang diperoleh dari kuesioner yang telah disebarkan kepada 60 responden.

1) Jurusan

Data responden dilihat dari data alumni Jurusan HES (Hukum Ekonomi Syariah) sebanyak 60 responden.

2) Jenis Kelamin

Adapun jenis kelamin responden, jurusan HES (Hukum Ekonomi Syariah) respoden laki-laki berjumlah 38 alumni dan responden perempuan sejumlah 22 alumni.

\section{b. Uji Validitas dan Reliabilitas}

\section{1) Uji Validitas}

Uji validitas bertujuan untuk mengukur valid atau tidaknya suatu item pernyataan, valid tidaknya item pernyataan bisa dilihat dari membandingkan nilai r-hitung dengan r-tabel, data dikatakan valid jika rhitung lebih besar dari r-tabel (r-hitung $>$ 
$\mathrm{r}_{- \text {tabel }}$ ). Distribusi nilai $\mathrm{r}$ tabel dengan taraf signifikan $5 \%$ adalah 0,25 . Jadi, jika $r$ hitung lebih besar dari 0,25 maka pernyataan tersebut dinyatakan valid. Semua data dalam penelitian ini sudah memenuhi uji validitas data.

\section{2) Uji Reliabilitas}

Berikut ini hasil uji reliabilitas dengan menggunakan program MSI (Method of Succesive Interval):

Tabel 4.7

Uji Reabilitas

\begin{tabular}{|c|c|c|c|}
\hline Case $P_{1}$ & ocessing $\mathrm{St}$ & $\mathrm{Imm}$ & lary \\
\hline & & $\mathrm{N}$ & $\%$ \\
\hline & Valid & 60 & 100.0 \\
\hline Cases & Excluded $^{\mathrm{a}}$ & 0 & .0 \\
\hline & Total & 60 & 100.0 \\
\hline Listwis & $\begin{array}{l}\text { deletion } b \\
\text { in the p }\end{array}$ & oced & $\begin{array}{l}\text { on all } \\
\text { lure. }\end{array}$ \\
\hline Reliability & Statistics & & \\
\hline Cronbach's & Cronbach' & & $\mathrm{N}$ of Items \\
\hline Alpha & Alpha B & sed & \\
\hline
\end{tabular}

\begin{tabular}{|l|l|l|}
\hline \multirow{2}{*}{} & on & \multirow{3}{*}{} \\
\cline { 2 - 2 } & Standardized & \\
\cline { 2 - 2 } & Items & \\
\hline .637 & .649 & 5 \\
\hline
\end{tabular}

Berdasarkan hasil pengujian reabilitas di atas, menunjukkan bahwa nilai Cronbach's Alpha yang dihasilkan adalah sebesar 0,637. Jadi angka tersebut $(0,637)$ lebih besar dari nilai minimal Cronbach's Alpha 0,6 $(0,637>0,6)$. Oleh karena itu dapat disimpulkan bahwa semua instrument penelitian yang digunakan untuk mengukur variable Eksistensi Jurusan HES dapat dikatakan reliable atau handal.

\section{3) Uji Asumsi Klasik}

\section{a) Uji Normalitas}

Adapun hasil uji normalitas sebagai berikut:

One-Sample Kolmogorov-Smirnov Test

\begin{tabular}{|c|c|c|c|c|}
\hline Model & $\mathbf{Z}$ & $\begin{array}{c}\text { Asymp.Sig } \\
\text { (2-tailed) }\end{array}$ & Kriteria & Kesimpulan \\
\hline $\begin{array}{c}\text { Unstandardized } \\
\text { Residual }\end{array}$ & 0,616 & 0,842 & $>0,05$ & $\begin{array}{c}\text { Data } \\
\text { Berdistribusi } \\
\text { Normal }\end{array}$ \\
\hline
\end{tabular}

Berdasarkan table di atas, diketahui bahwa nilai signifikansi sebesar 0,842. lebih besar dari 0,05, sehingga dapat disimpulkan bahwa data yang di uji berdistribusi normal.

\section{b) Uji Homoskedastisitas}

Salah satu cara untuk mengetahui ada tidaknya heteroskedastisitas dengan melakukan uji Scatterplot sebagai berikut: 


\section{Gambar 4.1}

\section{Hasil Uji Homoskedastisitas}

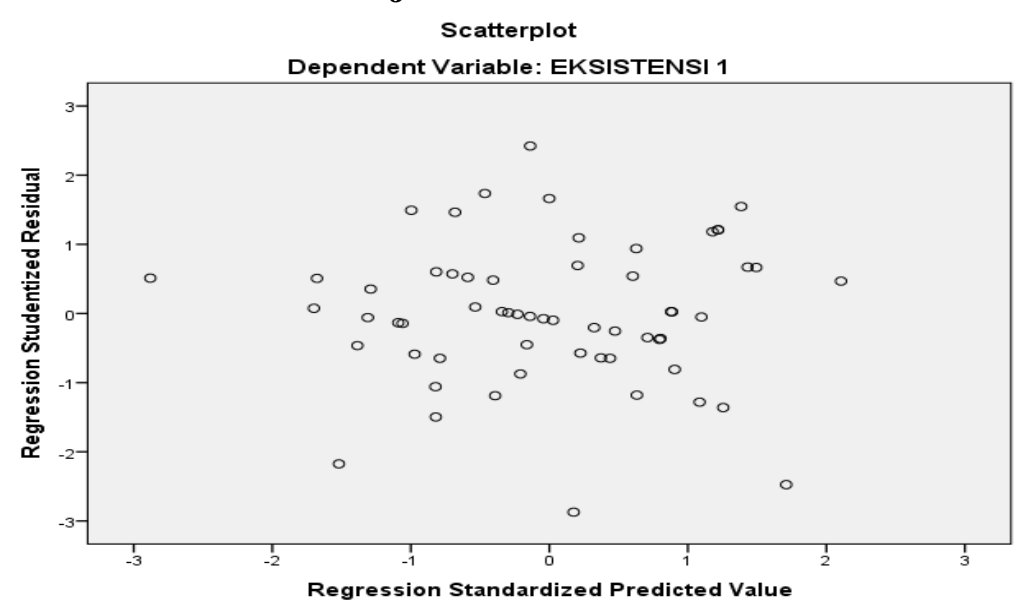

Dari gambar tersebut, terbebas dari gejala menunjukkan bahwa sebaran data heteroskedastisitas.

residual tidak membentuk pola tertentu dan menyebar dibawah dan diatas angka nol pada sumbu Y, dengan demikian model c) Uji Multikolonilieritas

Adapun hasil uji multikolonieritas sebagai berikut:

Tabel. 4.8

\section{Hasil Uji Multikolonieritas Variabel Kurikulum( $\left.\mathbf{X}_{1}\right)$}

\begin{tabular}{|c|c|c|c|c|c|c|c|}
\hline \multicolumn{8}{|l|}{ Coefficients $^{\mathrm{a}}$} \\
\hline Model & \multicolumn{2}{|c|}{ Unstandardized } & \multirow{2}{*}{\begin{tabular}{|l|} 
Standardized \\
Coefficients \\
\end{tabular}} & $\mathrm{t}$ & \multirow[t]{2}{*}{ Sig. } & \multicolumn{2}{|c|}{ Collinearity Statistics } \\
\hline & \multicolumn{2}{|c|}{ Coefficients } & & & & \multirow[b]{2}{*}{ Tolerance } & \multirow[b]{2}{*}{ VIF } \\
\hline - & $B$ & Std. Error & Beta & & I & & \\
\hline (Constan & & & & 10.96 & & & \\
\hline t) & 41.058 & 3.745 & & & .000 & & \\
\hline $\mathrm{X} 1$ & .029 & 092 & 041 & 310 & 757 & 1.000 & 1.000 \\
\hline
\end{tabular}

Dari hasil tersebut dapat dijelaskan bahwa nilai VIF (variance- inflating factor) untuk semua variabel bebas lebih kecil dari 10, artinya data tersebut terbebas dari multikolonieritas. Misalnya variabel $\mathrm{X}$, mempunyai nilai VIF sebesar 1,000, nilai ini lebih kecil dari 10 . 
INTIQAD: JURNAL AGAMA DAN PENDIDIKAN ISLAM

ISSN 1979-9950 (print) || ISSN 2598-0033 (online), http://jurnal.umsu.ac.id/index.php/intiqad DOI: https://doi.org/10.30596/intiqad.v11i1.2445

Vol. 11, No. 1 (Juni 2019)

Tabel. 4.9

Hasil Uji Multikolonieritas Variabel Mutu Dosen $\left(\mathbf{X}_{2}\right)$

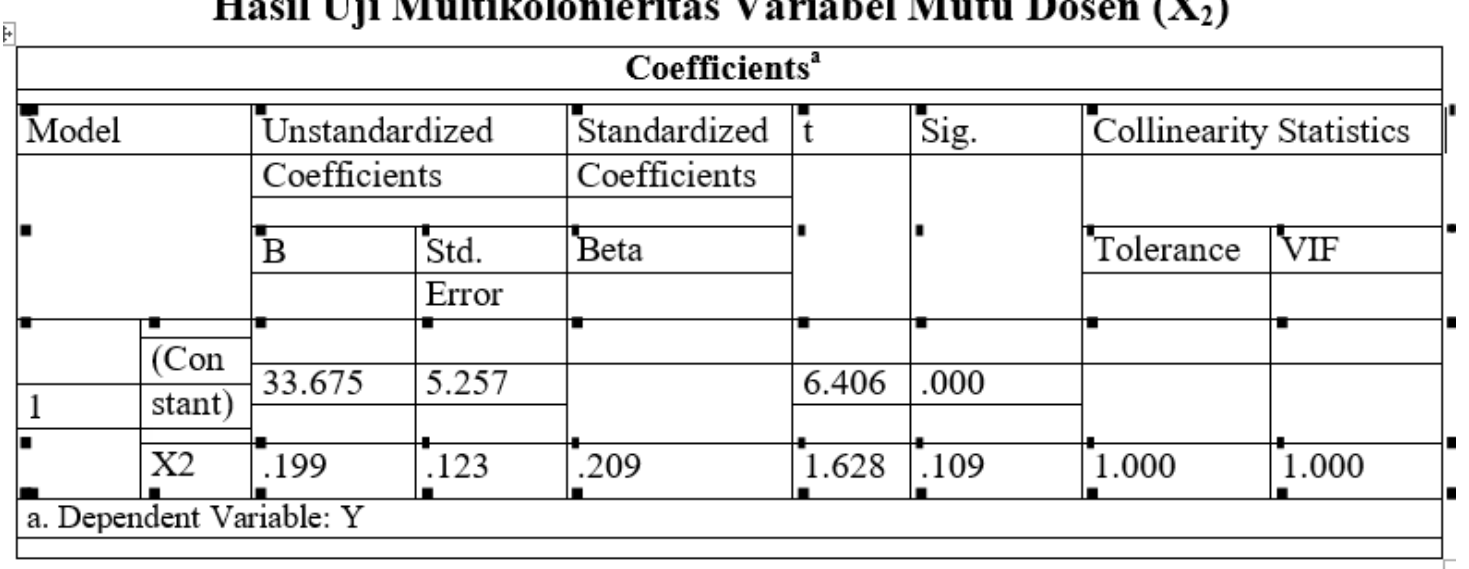

Dari hasil tersebut dapat Misalnya variabel $\mathrm{X}$, mempunyai nilai dijelaskan bahwa nilai VIF (variance- VIF sebesar 1,000, nilai ini lebih kecil inflating factor) untuk semua variabel dari 10.

bebas lebih kecil dari 10, artinya data tersebut terbebas dari multikolonieritas.

Tabel. 4.9

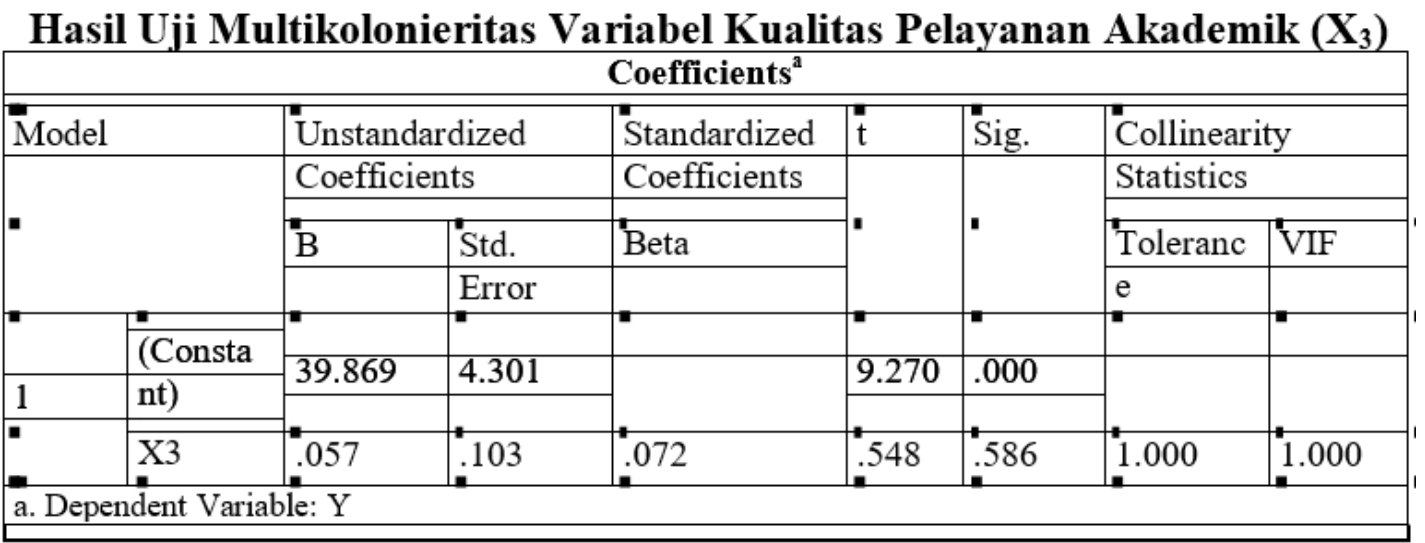

Dari hasil tersebut dapat dijelaskan bahwa nilai VIF (variance-inflating factor) untuk semua variabel bebas lebih kecil dari 10, artinya data tersebut terbebas dari multikolonieritas. Misalnya variabel $\mathrm{X}$, mempunyai nilai VIF sebesar 1,000, nilai ini lebih kecil dari 10 . 
Vol. 11, No. 1 (Juni 2019)

Tabel. 4.9

Hasil Uji Multikolonieritas Variabel Kompetensi Alumni $\left(\mathbf{X}_{4}\right)$

\begin{tabular}{|c|c|c|c|c|c|c|c|}
\hline \multicolumn{8}{|c|}{ Coefficients $^{\mathrm{a}}$} \\
\hline Model & Unstan & zed & Standardized & $\mathrm{T}$ & Sig. & Collinearit & Statistics \\
\hline \multirow{2}{*}{ 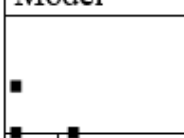 } & Coeffic & & Coefficients & \multirow[t]{2}{*}{ 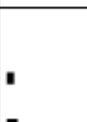 } & \multirow{2}{*}{ ' } & \multirow[b]{2}{*}{ Tolerance } & \multirow[b]{2}{*}{ VIF } \\
\hline & $B$ & Std. Error & Beta & & & & \\
\hline (Consta & & & & & & & \\
\hline nt) & 29.245 & 6.093 & & 4.800 & .000 & & \\
\hline $\mathrm{X} 4$ & 310 & .145 & 270 & 2.132 & 037 & 1.000 & 1.000 \\
\hline
\end{tabular}

Dari hasil tersebut dapat dijelaskan bahwa nilai VIF (variance- inflating factor) untuk semua variabel bebas lebih kecil dari 10, artinya data tersebut terbebas dari multikolonieritas. Misalnya variabel $\mathrm{X}$, mempunyai nilai VIF sebesar 1,000, nilai ini lebih kecil dari 10.

Tabel. 4.9

Hasil Uji Multikolonieritas Variabel Eksistensi Jurusan HES (Y)

\begin{tabular}{|c|c|c|c|c|}
\hline Variabel & Tolerance & VI & Kriteria & Kesimpulan \\
\hline Kurikulum & 0,822 & 1,217 & \multirow{4}{*}{$\begin{array}{l}\text { Tolerance } \geq \\
0,1 \text { VIF } \leq \\
10\end{array}$} & \multirow{4}{*}{$\begin{array}{l}\text { Terbebas } \\
\text { asumsi klasik } \\
\text { statistik } \\
\text { multikolinerit } \\
\text { as }\end{array}$} \\
\hline Mutu Dosen & 0,672 & 1,489 & & \\
\hline $\begin{array}{l}\text { Kualitas } \\
\text { Pelayanan } \\
\text { Akademik }\end{array}$ & 0,690 & 1,449 & & \\
\hline $\begin{array}{l}\text { Kompetensi } \\
\text { Alumni }\end{array}$ & 0,839 & 1,192 & & \\
\hline
\end{tabular}

Dari hasil tersebut dapat dijelaskan bahwa nilai VIF (varianceinflating factor) untuk semua variabel bebas lebih kecil dari 10, artinya data tersebut terbebas dari multikolonieritas.
Misalnya variabel $\mathrm{X}$, mempunyai nilai VIF sebesar 1,000, nilai ini lebih kecil dari 10 .

d) Uji Linieritas 
INTIQAD: JURNAL AGAMA DAN PENDIDIKAN ISLAM

ISSN 1979-9950 (print) || ISSN 2598-0033 (online), http://jurnal.umsu.ac.id/index.php/intiqad DOI: https://doi.org/10.30596/intiqad.v11i1.2445

Vol. 11, No. 1 (Juni 2019)

Tabel. 4.10

Hasil Uji Linieritas Variabel Kurikulum $\left(\mathbf{X}_{1}\right)$

\begin{tabular}{|c|c|c|c|c|c|c|c|}
\hline & & & NOVA Table & & & & \\
\hline & & & Sum of Squares & df & Mean & $F$ & Sig. \\
\hline & & & & & Square & & \\
\hline & & (Combined) & 98.688 & 14 & 7.049 & 1.143 & .350 \\
\hline P & Between Grouns & Linearity & 624 & 1 & 624 & 101 & 752 \\
\hline $\mathrm{Y} * \mathrm{X} 1$ & Detween UIOUps & $\begin{array}{l}\text { Deviation from } \\
\text { Linearity }\end{array}$ & 98.064 & 13 & 7.543 & 1.223 & .295 \\
\hline- & Within Groups & & 277.495 & 45 & 6.167 & & \\
\hline- & Total & & 376.183 & 59 & & I & 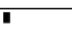 \\
\hline
\end{tabular}

Dari hasil output SPSS tersebut dapat disimpulkan bahwa nilai Sig. pada Deviation from Linierity yakni
$\mathrm{Y}^{*} \mathrm{X} 1=0,295$ lebih besar dari 0,05, maka dapat disimpulkan bahwa data tersebut bersifat linier.

Tabel. 4.10

Hasil Uji Linieritas Variabel Mutu Dosen $\left(\mathbf{X}_{2}\right)$

\begin{tabular}{|c|c|c|c|c|c|c|c|}
\hline & & ANOVA & Table & & & & \\
\hline 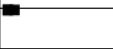 & & & Sum & $\mathrm{df}$ & Mean & $\mathrm{F}$ & Sig. \\
\hline & & & Squares & & Square & & \\
\hline & $\because$ & (Combined) & 79.896 & 10 & 7.990 & 1.321 & .246 \\
\hline I & Between Grouns & Linearity & 16.434 & 1 & 16.434 & 2.718 & .106 \\
\hline $\mathrm{Y}^{*} \mathrm{X} 2$ & & $\begin{array}{ll}\text { Deviation } & \text { from } \\
\text { Linearity } & \end{array}$ & 63.462 & 9 & 7.051 & 1.166 & .337 \\
\hline- & Within Groups & & 296.288 & 49 & 6.047 & 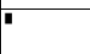 & 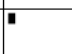 \\
\hline - & Total & & 376.183 & 59 & I & 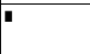 & I \\
\hline
\end{tabular}

Dari hasil output SPSS tersebut dapat disimpulkan bahwa nilai Sig. pada Deviation from Linierity yakni $\mathrm{Y}^{*} \mathrm{X} 2$
$=0,337$ lebih besar dari 0,05, maka dapat disimpulkan bahwa data tersebut bersifat linier.

Tabel. 4.10

\begin{tabular}{|c|c|c|c|c|c|c|c|}
\hline \multicolumn{8}{|c|}{ ANOVA Table } \\
\hline 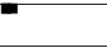 & & & Sum of & Df & Mean Square & $\mathrm{F}$ & Sig. \\
\hline \multirow[b]{4}{*}{ - } & & & Squares & & & & \\
\hline & & (Combined) & 141.399 & 14 & 10.100 & 1.936 & .048 \\
\hline & & Linearity & 1.935 & 1 & 1.935 & .371 & .546 \\
\hline & Between Groups & Deviation & & & & & \\
\hline \multirow{4}{*}{$\mathrm{Y}^{*} \mathrm{X} 3$} & & from & 139.465 & 13 & 10.728 & 2.056 & .373 \\
\hline & & Linearity & & & & & \\
\hline & \multicolumn{2}{|l|}{ Within Groups } & 234.784 & 45 & 5.217 & & \\
\hline & \multicolumn{2}{|l|}{ Total } & 376.183 & 59 & & & \\
\hline
\end{tabular}

Dari hasil output SPSS tersebut dapat disimpulkan bahwa nilai Sig. pada Deviation from Linierity yakni $\mathrm{Y} * \mathrm{X} 3=$
0,37 lebih besar dari 0,05, maka dapat disimpulkan bahwa data tersebut bersifat linier. 
INTIQAD: JURNAL AGAMA DAN PENDIDIKAN ISLAM

ISSN 1979-9950 (print) || ISSN 2598-0033 (online), http://jurnal.umsu.ac.id/index.php/intiqad DOI: https://doi.org/10.30596/intiqad.v11i1.2445

Vol. 11, No. 1 (Juni 2019)

Tabel. 4.10

Hasil Uji Linieritas Variabel Kompetensi Alumni $\left(\mathbf{X}_{4}\right)$

\begin{tabular}{|c|c|c|c|c|c|c|c|}
\hline \multicolumn{8}{|c|}{ ANOVA Table } \\
\hline \multirow{2}{*}{\multicolumn{3}{|c|}{ 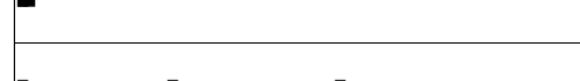 }} & Sum of & Df & Mean & $\mathrm{F}$ & Sig. \\
\hline & & & Squares & & Square & & \\
\hline \multirow{3}{*}{ - } & 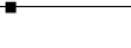 & (Combined) & 91.861 & 10 & 9.186 & 1.583 & .140 \\
\hline & Between & Linearity & 27.339 & 1 & 27.339 & 4.712 & .035 \\
\hline & Groups & Deviation from & & & & & \\
\hline \multirow{3}{*}{$\mathrm{Y} * \mathrm{X} 4$} & & Linearity & 64.522 & 9 & 7.169 & 1.236 & .296 \\
\hline & \multicolumn{2}{|c|}{ Within Groups } & 284.322 & 49 & 5.802 & & \\
\hline & \multicolumn{2}{|l|}{ Total } & 376.183 & 59 & & & \\
\hline
\end{tabular}

e) Uji Autokorelasi

Tabel. 4.12

Hasil Uji Autokorelasi

\begin{tabular}{|l|l|l|l|l|l|}
\hline \multicolumn{5}{|c|}{ Model Summary } \\
\hline Mode & $\mathrm{R}$ & R Square & Adjusted $\mathrm{R}$ & Std. Error of & Durbin- \\
\hline & & & Square & the Estimate & Watson \\
\hline 1 & $800^{\mathrm{a}}$ & .640 & 614 & 2.732 & 1.804 \\
\hline a. Predictors: (Constant), X4, X1, X3, X2 & & \\
\hline
\end{tabular}

Pada penelitian ini, jumlah variabel independent sebanyak 4 variabel yaitu Kurikulum, Mutu Dosen, Kualitas Pelayanan Akademik dan Kompetensi Alumni dengan jumlah sampel sebanyak 60 responen. Oleh karenanya nilai dL dan dU pada taraf signifikan 95\% pada table Durbin Watson adalah masing-masing 1,548 dan 1,616 (Lih. Tabel Durbin Watson)

Nilai $\mathrm{dL}=1,545$ (Dari Tabel DW)

Nilai dU = 1,616 (Dari Tabel DW))

Nilai DW $=1,804$ (Hasil output

SPSS) Nilai 4-dU = 4-1,616 = 2,384
Nilai 4-dL $=4-1,545=2,455$

Dari data di atas dapat diambil kesimpulan bahwa, DW berada diantara dU dan 4-dU, yaitu 1.616 < $1,804<2.348$, artinya tidak terjadi autokorelasi.

\section{4) Analisis Regresi Linier Berganda}

Pengujian dalam penelitian ini menggunakan regresi linier berganda. Analisis regresi linier berganda dimaksudkan untuk mengetahui pengaruh variabel-variabel bebas (independent) terhadap variabel terikat atau yang dipengaruhi (dependent). Pada penelitian ini yang menjadi variabel independent (X) adalah Kurikulum, 
INTIQAD: JURNAL AGAMA DAN PENDIDIKAN ISLAM

ISSN 1979-9950 (print) || ISSN 2598-0033 (online), http://jurnal.umsu.ac.id/index.php/intiqad DOI: https://doi.org/10.30596/intiqad.v11i1.2445

Vol. 11, No. 1 (Juni 2019)

Mutu Dosen, Kualitas Pelayanan dan Kompetensi Alumni, terhadap Akademik, dan Kompetensi Alumni, Eksistensi Jurusan HES. Pada sedangkan yang menjadi variabel dependent (Y) adalah Eksistensi Jurusan HES.

Analisis regresi linier berganda pada penelitian ini digunakan untuk mengetahui pengaruh variabel persepsi pelanggan, nilai Kurikulum, Mutu Dosen, Kualitas Pelayanan Akademik, penelitian ini yang menjadi variabel independent adalah Kurikulum $\left(\mathrm{X}_{1}\right)$, Mutu Dosen $\left(\mathrm{X}_{2}\right)$, Kualitas Pelayanan Akademik $\left(\mathrm{X}_{3}\right)$, dan Kompetensi Alumni $\left(\mathrm{X}_{4}\right), \quad$ sedangkan yang menjadi variabel dependent (Y) adalah Eksistensi Jurusan HES.

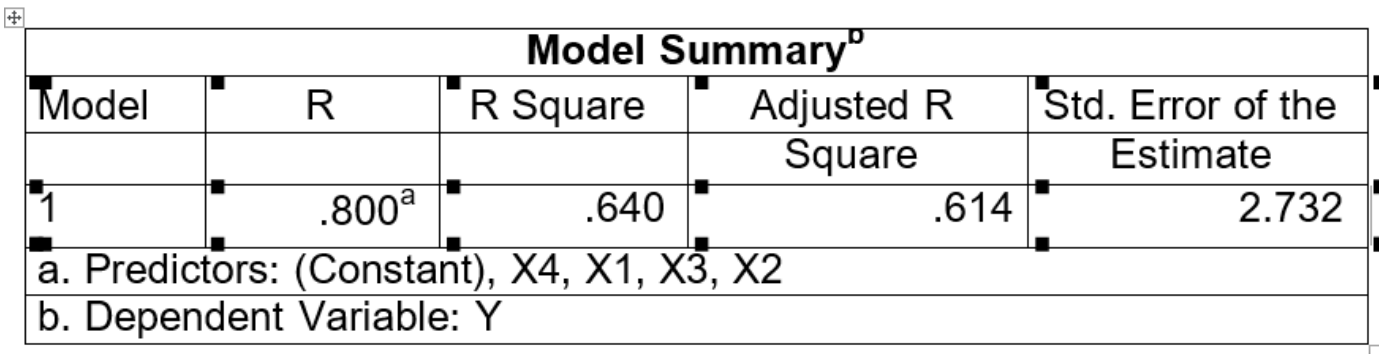

Jika ingin melihat seberapa besar variabel dependent dapat dijelaskan oleh variabel independent pada regresi linear berganda digunakan $R$ Square yang sudah disesuaikan atau Adjusted $R$ Square. Berdasarkan hasil analisis dengan menggunakan software SPSS versi 20.0 didapat nilai $\mathrm{R}^{2}$ yang telah disesuaikan (Adjusted $R \quad$ Square) sebesar 0,614, seperti yang terlihat pada table di atas Tabel Model Summary. Hal ini menunjukkan bahwa variabel yang dipilih pada variabel independent (Kurikulum, Mutu Dosen, Kualitas Pelayanan Akademik, dan Kompetensi
Alumni) dapat menerangkan

keragaman variabel dependent

(Eksistensi Jurusan HES) dengan kontribusi sebesar $61,4 \%$, sedangkan sisanya sebesar $38,6 \%$ diterangkan oleh variabel lain diluar variabel yang digunakan pada penelitian ini.

\section{5) Uji F-Statistik (Uji Koefisien}

\section{Regresi Secara Simultan)}

Uji $F$ pada penelitian ini merupakan uji yang dilakukan untuk melihat apakah terjadi pengaruh nyata antara variable independent terhadap variable dependent secara keseluruhan. Pengujian ini dapat dilakukan dengan 


\section{INTIQAD: JURNAL AGAMA DAN PENDIDIKAN ISLAM}

ISSN 1979-9950 (print) || ISSN 2598-0033 (online), http://jurnal.umsu.ac.id/index.php/intiqad DOI: https://doi.org/10.30596/intiqad.v11i1.2445

\section{Vol. 11, No. 1 (Juni 2019)}

menggunakan uji Fisher (F-Test) dengan cara membandingkan F-Hitung dengan F-tabel.

Dengan menggunakan signifikan 5 persen $(\alpha=5 \%)$ serta derajat kebebasan $(\delta \mathrm{f}) \mathrm{N}=\mathrm{n}-\mathrm{k}-1=60-5-1=$ 54, maka diperoleh nilai kritis D-tabel sebesar 2,54 sedangkan F-hitunganya 24.449, jadi F-hitung Lebih besar dari F-tabel $\quad(\mathrm{F}-$ hitung $=24.449>\mathrm{F}$ tabel $=2,54)$, ini berarti bahwa semua variable bebas (Independent Variable) yang digunakan berpengaruh seara signifikan (berarti) terhadap variable bebas (Eksistensi Jurusan HES). Bila nilai signifikansi sebesar $0,000<0,05$, artinya terdapat pengaruh yang signifikan antara kurikulum, mutu dosen, kualitas pelayan akademik dan kompetensi akademik terhadap eksistensi Jurusan HES, sehingga hipotesis $\mathrm{H}_{01}$ ditolak dan hipotesis $\mathrm{Ha}_{1}$ diterima. Hasil Uji F selengkapnya dapat dilihat pada Lampiran pada Tabel Model ANOVA.

\section{6) Uji t}

Uji $t$ pada penelitian ini bertujuan untuk mengetahui besarnya pengaruh masing-masing variabel independent secara individual (parsial) terhadap variabel dependent. Uji t dilakukan dengan melihat signifikansi thitung yang diperoleh dilakukan pembanding dengan alpha yang ditetapkan $(0,05)$ dan juga membandingkan thitung terhadap tabel (1,67). Dari hasil perhitungan uji regresi linier berganda seperti yang terlihat pada Tabel 13 atau dapat dilihat pada Lampiran menunjukkan :

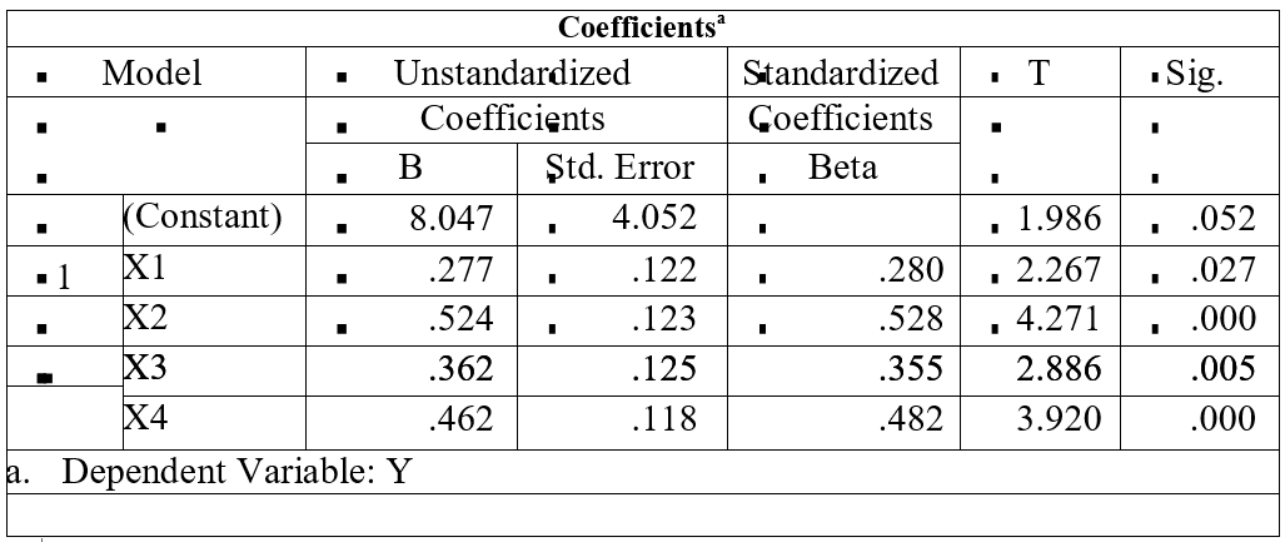

1) Hasil dari uji t variabel nilai signifikan sebesar 0,027 , Kurikulum $\left(\mathrm{X}_{1}\right)$ menunjukkan dimana nilainya lebih kecil dari 


\section{INTIQAD: JURNAL AGAMA DAN PENDIDIKAN ISLAM}

ISSN 1979-9950 (print) || ISSN 2598-0033 (online), http://jurnal.umsu.ac.id/index.php/intiqad DOI: https://doi.org/10.30596/intiqad.v11i1.2445

Vol. 11, No. 1 (Juni 2019)

nilai alpha yang telah ditetapkan $(0,05)$ dan nilai thitung $(2,267)$ lebih kecil daripada nilai tabel $(1,67)$, sehingga $\mathrm{H}_{02}$ ditolak dan $\mathrm{H}_{\mathrm{a} 2}$ diterima yang berarti kurikulum berpengaruh signifikan terhadap Eksistensi Jurusan HES.

2. Hasil dari uji $\mathrm{t}$ variabel mutu dosen $\left(\mathrm{X}_{2}\right)$ menunjukkan nilai signifikan sebesar 0,000 dimana nilainya lebih kecil dari nilai alpha yang telah ditetapkan $(0,05)$ dan nilai thitung $(4,271)$ lebih besar dari pada nilai tabel $(1,67)$, sehingga tolak $\mathrm{H}_{03}$ dan terima $\mathrm{H}_{\mathrm{a} 3}$ yang berarti nilai mutu dosen berpengaruh signifikan terhadap Eksistensi Jurusan HES.

3) Hasil dari uji t Kualitas Pelayanan Akademik $\left(\mathrm{X}_{3}\right)$ menunjukkan nilai signifikan sebesar 0,005 dimana nilainya lebih kecil dari nilai alpha yang telah ditetapkan $(0,05)$ dan nilai thitung $(2,886)$ lebih besar daripada nilai ttabel $(1,67)$, sehingga tolak $\mathrm{H} 04$ dan terima $\mathrm{H}_{\mathrm{a} 4}$ yang berarti Kualitas Pelayanan Akademik berpengaruh signifikan terhadap Eksistensi Jurusan HES.

4) Hasil dari uji t variabel Kompetensi Alumni $\left(\mathrm{X}_{4}\right)$ menunjukkan nilai signifikan sebesar 0,000 dimana nilainya lebih keil dari nilai alpha yang telah ditetapkan $(0,05)$ dan nilai thitung (3.920) lebih besar daripada nilai ttabel $(1,67)$, sehingga tolak $\mathrm{H}_{05}$ dan terima $\mathrm{H}_{\mathrm{a} 5}$ yang berarti Kompetensi Alumni berpengaruh signifikan terhadap Eksistensi Jurusan HES.

Tabel 13. Hasil Perhitungan Regresi Linier Berganda

\begin{tabular}{|l|r|r|r|}
\hline \multicolumn{1}{|c|}{ Variabel } & B & $\mathbf{T}_{\text {hitung }}$ & \multicolumn{1}{c|}{ Sig. } \\
\hline Constant & 8,047 & 1,986 & 0,052 \\
\hline Kurikulum $\left(\mathrm{X}_{1}\right)$ & 0,277 & 2,267 & 0,027 \\
\hline Mutu Dosen $\left(\mathrm{X}_{2}\right)$ & 0,524 & 4,271 & 0,000 \\
\hline Kualitas Pelayanan Akademik $\left(\mathrm{X}_{3}\right)$ & 0,362 & 2,886 & 0,005 \\
\hline Kompetensi Alumni $\left(\mathrm{X}_{4}\right)$ & 0,462 & 3,920 & 0,000 \\
\hline
\end{tabular}

Berdasarkan hasil yang diperoleh dalam penelitian ini didapatkan bahwa semua variabel yang memiliki pengaruh yang signifikan terhadap Eksistensi 


\section{INTIQAD: JURNAL AGAMA DAN PENDIDIKAN ISLAM}

ISSN 1979-9950 (print) || ISSN 2598-0033 (online), http://jurnal.umsu.ac.id/index.php/intiqad DOI: https://doi.org/10.30596/intiqad.v11i1.2445

\section{Vol. 11, No. 1 (Juni 2019)}

Jurusan HES. Sedangkan variabel yang memberikan pengaruh paling besar terhadap Eksistensi Jurusan HES adalah mutu dosen. Berdasarkan pernyataan di atas maka dapat disimpulkan sebagai berikut:

Tabel. 4.14

Pengujian Hipotesis

\begin{tabular}{|l|r|l|l|}
\hline Hipotesis & t hitung & t tabel & Keterangan \\
\hline $\begin{array}{l}\text { Kurikulum berpengaruh langsung terhadap Eksistensi } \\
\text { Jurusan HES }\end{array}$ & 2,267 & 1,67 & Diterima \\
\hline $\begin{array}{l}\text { Mutu Dosen berpengaruh langsung terhadap } \\
\text { Eksistensi Jurusan HES }\end{array}$ & 4,271 & 1,67 & Diterima \\
\hline $\begin{array}{l}\text { Kualitas Pelayanan Akademik berpengaruh langsung } \\
\text { terhadap Eksistensi Jurusan HES }\end{array}$ & 2,886 & 1,67 & Diterima \\
\hline $\begin{array}{l}\text { Kompetensi Alumni berpengaruh langsung terhadap } \\
\text { Eksistensi Jurusan HES }\end{array}$ & 3,920 & 1,67 & Diterima \\
\hline
\end{tabular}

\section{Pembahasan Penelitian}

Penelitian ini mengemukakan empat hipotesis. Untuk menguji hipotesis tersebut maka dihitung nilai t-hitung. Kemudian nilai t-hitung tersebut dibandingkan dengan nilai ttabel. Apabila t-hitung > t-tabel maka hipotesis diterima.

Hipotesis pertama $\left(\mathrm{H}_{1}\right)$ adalah: Kurikulum $\left(\mathrm{X}_{1}\right)$ berpengaruh langsung terhadap Eksistensi Jurusan HES (Y). Berdasarkan hasil analisis data didapat bahwa koefisien hubungan antara $X_{1}$ dan $\mathrm{Y}$ sebesar 0.22 dengan nilai $\mathrm{t}$ hitung yang dihasilkan adalah sebesar 2,267. Nilai ini lebih besar dari nilai ttabel sebesar 1,67. Oleh karenanya hipotesis yang diajukan dalam penelitian ini dapat diterima $\left(\mathrm{Ha}_{1}\right.$ diterima). Hasil ini semakin memperkuat pendapat peneliti yang menegaskan bahwa konsep Kurikulum yang digunakan merupakan salah satu konsep untuk meningkatkan Eksistensi Jurusan HES.

Hipotesis Kedua $\left(\mathrm{H}_{2}\right)$ adalah: Mutu Dosen $\left(\mathrm{X}_{2}\right)$ berpengaruh langsung terhadap Eksistensi (Y). Berdasarkan hasil analisis data didapat bahwa koefisien hubungan antara $\mathrm{X}_{2}$ dan $\mathrm{Y}$ sebesar 0.22 dengan nilai thitung yang dihasilkan adalah sebesar 4,271. Nilai ini lebih besar dari nilai ttabel sebesar 1,67. Oleh karenanya hipotesis yang diajukan dalam penelitian ini dapat diterima $\left(\mathrm{H}_{2}\right.$ diterima). Hasil ini 
Vol. 11, No. 1 (Juni 2019)

sejalan dengan hasil penelitian Yusran Razak, dkk (2016), dan penelitian ini memperkuat peneliti bahwa Mutu Dosen dapat memberikan pengaruh terhadap pengembangan perguruan tinggi. Eksistensi Jurusan HES akan terlihat apabila mutu dosen memberikan pengaruh positif terhadap keberadaan prodi tersebut, karena kurikulum dan mutu dosen dalam proses belajar mengajar saling mempengaruhi baik secara langsung maupun tidak langsung.

Hipotesis ketiga $\left(\mathrm{H}_{3}\right)$ adalah: Kualitas pelayanan akademik $\left(\mathrm{X}_{3}\right)$ berpengaruh langsung terhadap eksistensi Jurusan HES (Y). Berdasarkan hasil analisis data didapat bahwa koefisien hubungan antara $X_{1}$ dan $\mathrm{X}_{2}$ sebesar 0.22 dengan nilai $\mathrm{t}$ hitung yang dihasilkan adalah sebesar 2,886. Nilai ini lebih besar dari nilai ttabel sebesar 1,67. Oleh karenanya hipotesis yang diajukan dalam penelitian ini dapat diterima $\left(\mathrm{H}_{3}\right.$ diterima $)$. Hasil ini sejalan dengan hasil penelitian Nyoman Rinala, dkk (2013), dan penelitian ini memperkuat peneliti bahwa Kualitas Pelayanan akademik dapat memberikan pengaruh positif, karena Kualitas Pelayanan akademik akan saling mempengaruhi baik langsung maupun tidak langsung.

Hipotesis Keempat $\left(\mathrm{H}_{4}\right)$ adalah: Kompetensi Alumni $\left(\mathrm{X}_{4}\right)$ berpengaruh langsung terhadap Eksistensi (Y). Berdasarkan hasil analisis data didapat bahwa koefisien hubungan antara $\mathrm{X}_{4}$ dan $\mathrm{Y}$ sebesar 0.22 dengan nilai $\mathrm{t}$ hitung yang dihasilkan adalah sebesar 3,920. Nilai ini lebih besar dari nilai t-tabel sebesar 1,67. Oleh karenanya hipotesis yang diajukan dalam penelitian ini dapat diterima $\left(\mathrm{H}_{4} \quad\right.$ diterima $)$. Eksistensi Jurusan HES akan terlihat apabila Kompetensi Alumni memberikan pengaruh positif terhadap keberadaan prodi tersebut, karena Kompetensi Alumni dapat memberikan dampak langsung di dunia kerja maka dari itu Kompetensi Alumni dapat mempengaruhi baik secara langsung maupun tidak langsung. Hasil ini sejalan dengan hasil penelitian Kamaruddin (2015), dan penelitian A. Said Hasan Basri (2011), Alumni sebagai produk akhir yang dihasilkan perguruan tinggi keberadaannya berperan penting bagi kualitas dan eksistensi dari perguruan tinggi yang meluluskannya. Oleh sebab itu, upaya strategis dalam rangka memperhatikan keberadaan alumni ini harus dilakukan, karena selain menjadi 
Vol. 11, No. 1 (Juni 2019)

sasaran mutu sebuah perguruan tinggi, alumni juga menjadi media evaluasi dan tolak ukur kesuksesan sebuah perguruan tinggi. Jurusan HES sebagai salah satu unit dari Fakultas Syariah AIN Langsa, hendaknya juga melakukan upaya strategis melalui penelitian pelacakan alumni (Tracer Study), menjalin hubungan dan kerjasama dengan alumni, serta mempersiapkan calon alumni yang kompeten dan berkualitas. Ketiga langkah strategis ini dapat menjadi solusi bagi eksistensi Jurusan HES sebagai penyelenggara pendidikan yang terpercaya, unggul dan terkemuka dalam pandangan stakeholder.

Berdasarkan hasil penelitian di atas maka dapat disimpulkan semua variable yang digunakan dalam penelitian ini mempunya pengaruh positif terhadap eksistensi Jurusan Hukum Ekonomi Syariah. Adapun variable mutu dosen merupakan variable yang paling besar pengaruhnya terhadap eksistensi Jurusan Hukum Ekonomi Syariah. Hal ini dibuktikan dengan hasil analisis data yang didapat bahwa koefisien hubungan antara $\mathrm{X}_{2}$ dan $\mathrm{Y}$ sebesar 0.22 dengan nilai $\mathrm{t}$ hitung yang dihasilkan adalah sebesar 4,271 yang merupakan nilai t-hitung tertinggi dibandingkan dengan t-hitung variable yang lain. Ini berarti bahwa mutu dosen yang mengajar di Jurusan Hukum Ekonomi Syariah sudah baik.

\section{E. Simpulan}

Berdasarkan dari hasil analisis yang dilakukan dengan menggunakan model analisis regresi linier berganda dengan menggunakan software SPSS. 20 mengenai analisis faktor-faktor yang mempengaruhi variabel independen yang terdiri dari kurikulum, mutu dosen, kualitas pelayanan akademik dan kompetensi alumni terhadap eksistensi Jurusan Hukum Ekonomi Syariah IAIN Langsa. Maka dari hasil penelitian ini dapat diambil kesimpulan sebagai berikut:

1. Kurikulum (X1) berpengaruh langsung terhadap Eksistensi Jurusan HES (Y). Berdasarkan hasil analisis data didapat bahwa koefisien hubungan antara $\mathrm{X}_{1}$ dan $\mathrm{Y}$ sebesar 0.22 dengan nilai $\mathrm{t}$ hitung yang dihasilkan adalah sebesar 2,267. Nilai ini lebih besar dari nilai t-tabel sebesar 1,67. Oleh karenanya hipotesis yang diajukan dalam penelitian ini dapat diterima (Ha1 diterima). Hasil ini semakin memperkuat pendapat 
peneliti yang menegaskan bahwa konsep Kurikulum yang digunakan merupakan salah satu factor untuk meningkatkan Eksistensi Jurusan HES.

2. Mutu Dosen (X2) berpengaruh langsung terhadap Eksistensi (Y). Berdasarkan hasil analisis data didapat bahwa koefisien hubungan antara $\mathrm{X}_{2}$ dan $\mathrm{Y}$ sebesar 0.22 dengan nilai t-hitung yang dihasilkan adalah sebesar 4,271. Nilai ini lebih besar dari nilai ttabel sebesar 1,67. Oleh karenanya hipotesis yang diajukan dalam penelitian ini dapat diterima $\left(\mathrm{H}_{2}\right.$ diterima). Mutu dosen memberikan pengaruh positif dan signifikan terhadap Eksistensi Jurusan HES.

3. Kualitas pelayanan akademik (X3) berpengaruh langsung terhadap eksistensi Jurusan HES (Y). Berdasarkan hasil analisis data didapat bahwa koefisien hubungan antara $X_{1}$ dan $X_{2}$ sebesar 0.22 dengan nilai t-hitung yang dihasilkan adalah sebesar 2,886. Nilai ini lebih besar dari nilai ttabel sebesar 1,67. Oleh karenanya hipotesis yang diajukan dalam penelitian ini dapat diterima $\left(\mathrm{H}_{3}\right.$ diterima). Maka Kualitas Pelayanan Akademik berpengaruh secara positif dan signifikan terhadap Eksistensi Jurusan HES.

4. Kompetensi Alumni

(X4) berpengaruh langsung terhadap Eksistensi (Y). Berdasarkan hasil analisis data didapat bahwa koefisien hubungan antara $\mathrm{X}_{4}$ dan $\mathrm{Y}$ sebesar 0.22 dengan nilai $\mathrm{t}$ hitung yang dihasilkan adalah sebesar 3,920. Nilai ini lebih besar dari nilai t-tabel sebesar 1,67. Oleh karenanya hipotesis yang diajukan dalam penelitian ini dapat diterima ( $\mathrm{H}_{4}$ diterima). Kompetensi Alumni memberikan pengaruh positif dan Sinifikan terhadap Eksistensi Jurusan HES.

5. Dari beberapa variabel yang sudah diuji yaitu kurikulum, mutu dosen, kualitas pelayanan akademik dan kompetensi alumni yang berpengaruh dominan terhadap eksistensi Jurusan Hukum Ekonomi Syariah yaitu variabel mutu dosen dengan melihat koefisien hubungan antara $\mathrm{X}_{2}$ dan $\mathrm{Y}$ sebesar 0.22 dengan nilai t-hitung yang dihasilkan 
INTIQAD: JURNAL AGAMA DAN PENDIDIKAN ISLAM

ISSN 1979-9950 (print) || ISSN 2598-0033 (online), http://jurnal.umsu.ac.id/index.php/intiqad DOI: https://doi.org/10.30596/intiqad.v11i1.2445

Vol. 11, No. 1 (Juni 2019)

adalah sebesar 4,271 yang merupakan nilai t-hitung tertinggi dibandingkan dengan t-hitung variable yang lain. Ini berarti bahwa mutu dosen yang mengajar di Jurusan Hukum Ekonomi Syariah sudah baik. Maka dapat dibuktikan bahwa variabel mutu dosenlah yang mempunyai pengaruh yang paling kuat dan signifikan terhadap Eksistensi Jurusan Hukum Ekonomi Syariah.

\section{Daftar Pustaka}

A. Said Hasan Basri, "Eksistensi dan Peran Alumni dalam Menjaga Kualitas Mutu Fakultas Dakwah", Jurnal Dakwah, Vol. XI, No. 1 Tahun 2011

Ashar, Strategi Pengembangan Program Studi Al-Ahwal Asysayksiyyah (AHS) Jurusan Syariah dan Ekonomi Islam STAIN Samarinda, Jurnal Fenomena, Vol. 6 No 2, 2014. Asrifianti, Sartika. (2017). Analisis Faktor-Faktor Yang Mempengaruhi Keputusan Masyarakat Muslim Di Kota
Binjai Tidak Menjadi Nasabah

Bank Syariah. Medan: USU.

BSNP, Pedoman Penyusunan Kurikulum Tingkat Satuan Pendidikan Jenjang Sekolah Dasar. Jakarta: BSNP, 2008.

Chariri, A. dan Ghazali, Imam. (2007).

Teori Akuntansi. Semarang:

Balai Penerbit Universitas

Diponogoro, 2007.

Dakir, Perencanaan dan Pengembangan Kurikulum, Yogyakarta: Rineka Cipta, 2004.

Frizimmons, J. A and Mona, J.

Frizimmons. (2001). Service

Management: opration, Strategy and InformationTechnology.

NewYork: Mc Graw-Hill.

Hair, dkk. (2006). Multivariate Data Analysis, Sixth Edition. Prentice

Hall: Pearson Education International.

Isnaini, et. al. (2013). Pedoman Praktikum SPSS \& Bank Mini. Medan: Fakultas Syariah dan Ekonomi Islam.

Kadir. (2015). Statistika Terapan. Konsep, Contoh dan Analisis Data dengan Program SPSS/Lisrel dalam Penelitian. Jakarta: Raja Grafindo Persada. 
ISSN 1979-9950 (print) || ISSN 2598-0033 (online), http://jurnal.umsu.ac.id/index.php/intiqad DOI: https://doi.org/10.30596/intiqad.v11i1.2445

Vol. 11, No. 1 (Juni 2019)

Kamaruddin, Peran Alumni Dalam Pengembangan Stain Menuju Alih Status,Jurnal al-IZZAH, Vol. 10 No. 2, November 2015.

Kustumastuti, Dyah. (2001). Manajemen Sistem Pengembangan Sumber Daya Dosen Sebagai Penjamin Mutu Di Perguruan Tinggi, Studi: Pengaruh Kompetensi Individu Terhadap Kinerja Dosen Yang Berorientasi Pada Mutu Dengan Moderator Iklim Organisasi Dan Dukungan Sumber Daya di Institut Teknologi Bandung (ITB), UPI, Bandung.

Listya Istiningtyas, Survei Kepuasan Alumni Terhadap Kualitas Pelayanan Progran Studi Psikologi Islam Fakultas

Ushuluddin dan Pemikiran Islam UIN Raden Fatah Palembang, Jurnal PSIKIS Vol. 1 No.2, 2015.

Nyoman Rinala, dkk, "Pengaruh Kualitas Pelayanan Akademik Terhadap Kepuasan dan Loyalitas Mah asiswa pad a Sekolah Tinggi Pariwisata Nusa Dua Bali", e-Journal Program Pascasarjana Universitas
Pendidikan Ganesha Program Studi Administrasi Pendidikan (Vol. 4, 2013).

Prima Aswirna, dkk. (2016). Laporan Penelitian: Pengaruh Kualitas Alumni Terhadap Penyerapan Dunia Kerja Dan Kepercayaan Masyarakat Tentang Perguruan Tinggi, IAIN Imam Bonjol, Padang.

Riduwan dan Kuncoro, Engkos Achmad. (2018). Analisis Jalur: Path Analysis. Edisi 2. Bandung: Alfabeta.

Sarjono, Julianita. (2011). SPSS Vs LISREL, Sebuah Pengantar Aplikasi Untuk Riset. Jakarta: Salemba Empat.

Siregar, Sofyan. (2014). Statistik Parametrik Untuk Penelitian Kuantitatif. Jakarta: Bumi Aksara.

Sugiyono. (2011). Metode Penelitian Kombinasi (Mixed Methods). Bandung: Alfabeta, 2011.

Sujuko, Efferin dkk. (2008). Metode Penelitian Akuntansi.

Yogyakarta: Graha Ilmu.

Tjahjadi, Simon Petrus Lili. (2007). Tuhan Para Filsuf dan Ilmuwan. Yogyakarta: Kanisius. 
INTIQAD: JURNAL AGAMA DAN PENDIDIKAN ISLAM

ISSN 1979-9950 (print) || ISSN 2598-0033 (online), http://jurnal.umsu.ac.id/index.php/intiqad DOI: https://doi.org/10.30596/intiqad.v11i1.2445

Vol. 11, No. 1 (Juni 2019)

Trianto, Budi. (2016). Riset Modeling.

Pekanbaru: Adh-Dhuha Institute.

Wahyono, Teguh. (2009). 25 Model

Analisis Statistik dengan

SPSS 17, Jakarta: PT. Elex

Media Komputindo.

Waris, Abd. (2015). Strategi
Pengembangan Mutu Perguruan

Tinggi Agama Islam Berbasis

Pesantren. UIN Malang. 